\title{
The Effectiveness of Group Counseling With Cognitive Restructuring and Self-Management Techniques to Reduce Academic Procrastination
}

\author{
Mela Elfida Putri ${ }^{\bowtie}$, Mungin Eddy Wibowo, Sugiyo Sugiyo \\ Universitas Negeri Semarang, Indonesia
}

\begin{tabular}{|c|c|}
\hline Article Info & Abstract \\
\hline $\begin{array}{l}\text { History Articles } \\
\text { Received: } \\
\text { 5 January } 2021 \\
\text { Accepted: } \\
\text { 11 February2021 } \\
\text { Published: } \\
30 \text { April } 2021 \\
\text { Keywords: } \\
\text { Cognitive } \\
\text { restructuring, } \\
\text { Self-management, } \\
\text { Academic } \\
\text { Procrastination }\end{array}$ & $\begin{array}{l}\text { Academic procrastination truly disadvantages students' learning achievement. } \\
\text { Hence, interventions to reduce this procrastination rate becomes significant. To } \\
\text { realize effort, the current study attempted to examine the effectiveness of group } \\
\text { counseling with cognitive restructuring and self-management techniques to } \\
\text { reduce students' academic procrastination. This experimental study involved } \\
24 \text { students selected using purposive random sampling. For the instrument, } \\
\text { questionnaire was used to collect the data of their academic procrastination, } \\
\text { while two-way ANOVA was to perform the analysis. Based on the results, the } \\
\text { group counseling with cognitive restructuring, self-management techniques, } \\
\text { and their combination worked effectively to reduce academic procrastination. } \\
\text { It was also found that the group counseling with the combination of both } \\
\text { techniques performed better than the use of each technique separately. At last, } \\
\text { this study was focused on combining cognitive restructuring and self- } \\
\text { management techniques to reduce students' academic procrastination. }\end{array}$ \\
\hline
\end{tabular}




\section{INTRODUCTION}

Students' success can be determined by their academic assignment completion. Peters (2004) considers that interest in completing assignment becomes one of determining factors affecting students' success. Further, Clare, et al (2000) explain negligent behavior or failure at completing tasks is one of students' undesired things.

Negligence is significantly related to procrastination. Steel (2007) deems procrastination as a desired intentional postponement although the individuals know that it contributes to negative effects. For more, Steel (2010) thinks that procrastination is an intentional postponement by individuals for their tasks/ works although they now this can be troublesome in the future.

Flore (2012: 6) mentions procrastination is a mechanism to cope with anxiety related to starting or completing every task or decision. Meanwhile, Tuckman (2002) asserts procrastination is an unnecessary habit of delaying done by somebody due to the fear of failure and unperfect work so that the person will feel safe to not doing it immediately due to the fear.

Counselors exactly have important roles in helping students reducing academic procrastination. One of strategies that can be done is to use techniques during counseling sessions. Some possible techniques to deal with this issue are cognitive restructuring and selfmanagement techniques.

According to Elford, cognitive restructuring involves the application of learning principles in mind. It proves that this technique can be used in cognitive behavioral counseling which focuses on individuals' behavior and thoughts. This technique will help individuals manage to learn cognitive distortion or deny the basis of "wrong thinking" with the aim of restructuring irrational thoughts into rational ones.

Cognitive restructuring is the most often technique used to change less adaptive individual's mindset (Maag, 2004). Within it, one is taught to change wrong thoughts so to become realistic.

DuPaul, Junod, and Flammer (2006: 143) state self-management has been used for children to encounter various academic problems and behavior. Vargas (2009: 350) adds self-management function has been proved by American in several issues such as procrastination, obesity, alcoholism, risky sexual practices, drugs abuse, smoking, failure in trainings, increased credit card debt, and so on, including procrastination.

Cormie and Cormier in Nursalim (2013:15) self-management is a therapeutic process in which counselees direct their behavior using one or more combinative therapeutic strategies. At this rate, possible strategies to apply self-management are such as selfmonitoring, stimulus control, and self-reward. Ozer, et al (2009) found 52\% Turkish students often do academic procrastination, while Khan, et al (2014) conclude that students tend to submit their assignment lately.

Erfantinni, et al (2016) suggests to use cognitive restructuring technique to reduce students' academic score because this technique gives no effectiveness difference in both male and female students, so it offers equal results in reducing academic procrastination for all. Besides, findings of this study are also relevant to what was done by Saputra, et al (2017) that cognitive restructuring technique can reduce students' academic procrastination tendency.

Corey (2013: 265) mentions four strategies of self-management, namely selfmonitoring, self-reward, self-contracting, and stimulus control.

One of the goals of this approach is to assist students with managing, monitoring, and evaluating themselves in order to achieve better behavioral changes or responsibility. Therefore, to reduce students' academic procrastination behavior, the researchers employed group counseling service with self-management as a part of behavioral approach.

Behavioral approach has some specific techniques, for example positive reinforcement, token economy, shaping, behavior contract, 
modelling, self-management, extinction, flooding, satitation, punishment, and systematic desensitization.

One possible strategy to do by counsellors to help students reduce physical aggression is by giving them group service. In this study, the service was CBT group counseling.

Group counseling is a process of problem-oriented assistance provided to members to find strengths to overcome problems arising from dynamic interactions in groups (Corey, 2012).

This study strived to examine the intervention of CBT group counseling with cognitive restructuring and self-management techniques to reduce students' academic procrastination. It was expected that this intervention would reduce students' academic procrastination.

\section{METHODS}

There were 24 students with high level of academic procrastination involved as the experimental subjects. They were grouped into 4 consisting of 6 students in each group. In addition, the collect their data the researchers used psychological scale adopted from McCloskey (2011); Alexandrova (2015); and $\mathrm{He}$ (2017). This scale is called the Academic
Procrastination Scale (APS). APS was designed to determine the level of individual academic procrastination. There are 25 items with a Cronbach Alpha of 0.815 .

Two-way ANOVA test was utilized to analyze the data, while the research method was experimental with $2 \times 2$ factorial design.

Several experimental procedures were done in this study. First, the provision of pretest using academic procrastination scale. Second, the implementation of CBT group counseling (cognitive restructuring and self-management techniques) as interventions in 5 sessions for group 1, (cognitive restructuring) in 5 sessions for group 2, (self-management) in 5 sessions for group 3 and group which got not treatment received 5 sessions for group 4 . This group 4 was the control group.

Furthermore, each group was assigned to take posttest in the fifth session of group counseling. The results of the posttest of each group were analyzed and examined in terms of changes before and after the treatment was given, compared to see any differences between those which received the group counseling with techniques and non-technique, and determine interactions on each group. Systematically, the activities done in the group counseling with cognitive restructuring and self-management techniques are elaborated in the following table 1.

Table 1. The systematics of the activities done in the group counseling with cognitive restructuring and self-management techniques

\begin{tabular}{lll}
\hline Sessions & Cognitive Restructruring & Self-Management \\
\hline 1 & $\begin{array}{l}\text { Building cohesiveness and formulating } \\
\text { goals }\end{array}$ & $\begin{array}{l}\text { Building cohesiveness and formulating } \\
\text { goals }\end{array}$ \\
\hline 2 & $\begin{array}{l}\text { Discussing the concept of changing } \\
\text { negative thoughts into positive thoughts }\end{array}$ & $\begin{array}{l}\text { Identifying specific behaviors to change } \\
\text { independently and responsibly }\end{array}$ \\
\hline 3 & $\begin{array}{l}\text { Identifying negative thoughts signs and } \\
\text { responding them with positive thoughts } \\
\text { Exploring negative thoughts management } \\
\text { strategies }\end{array}$ & Learning right and proper behavior \\
4 & Evaluating results and follow-up & Evaluating results and follow-up \\
\hline 5
\end{tabular}




\section{RESULTS AND DISCUSSION}

Data description of this study indicated that the level of mean and standard deviation of the experimental group academic procrastination experienced reduction viewed from pretest and posttest data comparison. In details, group one which used cognitive restructuring and self-management obtained $(\mathrm{M}$ $=81.50 ; \mathrm{SD}=5.049)$ for the pretest and $(\mathrm{M}=$ 32.33 ; $\mathrm{SD}=4.71)$ for the posttest. In the group counselling with cognitive restructuring technique, the pretest data were $(\mathrm{M}=81.33$; SD $=4.80$ ), while for the posttest this group gained
$(\mathrm{M}=42.67 ; \mathrm{SD}=7.58)$. Similar to the previous two groups, the group counselling with selfmanagement technique got $(\mathrm{M}=80.00 ; \mathrm{SD}=$ 5.51) for the pretest and $(M=53.17 ; S D=9.98)$ for the posttest. Meanwhile, the control group obtained $(\mathrm{M}=79.33$; $\mathrm{SD}=5.64)$ during the pretest and $(\mathrm{M}=64.83 \mathrm{SD}=9.51)$ for the postest. The complete results are presented in table 2. Table 2. The results of the group counseling effectiveness test with cognitive restructuring, self-management and the combination of cognitive restructuring and selfmanagement

Table 2. The results of the group counseling effectiveness test with cognitive restructuring, selfmanagement and the combination of cognitive restructuring and self-management

\begin{tabular}{lllllll}
\hline \multirow{2}{*}{ Techniques } & \multicolumn{2}{l}{ Pretest Scores } & \multicolumn{2}{l}{ Posttest Scores } & \multirow{2}{*}{$\mathrm{P}$} \\
\cline { 2 - 5 } & $\mathrm{M}$ & $\mathrm{SD}$ & $\mathrm{M}$ & $\mathrm{SD}$ & & \\
\hline CR\&SM & 81.50 & 5.04 & 32.33 & 4.71 & 3.631 & $<0.05$ \\
CR & 81.33 & 4.80 & 42.67 & 4.22 & 4.863 & $<0.05$ \\
$\mathrm{SM}$ & 80.00 & 5.51 & 53.16 & 9.98 & 7.282 & $<0.05$ \\
Control & 79.33 & 5.64 & 64.83 & 9.51 & 1.631 & $>0.05$ \\
\hline
\end{tabular}

According to table 2, each group of cognitive restructuring, self-management, and the combination of these techniques was able to reduce students' academic procrastination. In addition to this, the results of two-way anova on Test of Between-Subject Effects presented mean differences in the procrastination value based on the implementation of cognitive restructuring technique group $(\mathrm{F}=90.108, \mathrm{p}<0.05)$ which indicated the effect of cognitive restructuring implementation to students' academic procrastination, self-management technique group $(\mathrm{F}=152,669, \mathrm{p}<0.05)$ which showed the effect of self-management technique implementation to students' academic procrastination value, and the combination group $(F=63.441, p<0.05)$ which yielded the combination of cognitive restructuring and selfmanagement techniques group jointly gave some effects to the value of students' academic procrastination. All these results can be seen in the following table 3. Table 3. The Interaction Effects of cognitive restructuring group, selfmanagement group, and the combination of cognitive restructuring and self-management group

Table 3. The Interaction Effects of cognitive restructuring group, self-management group, and the combination of cognitive restructuring and self-management group

\begin{tabular}{lll}
\hline Effects & $\mathrm{F}(1,20)$ & $\mathrm{P}$ \\
\hline $\mathrm{CR}$ & 90.108 & $<0.05$ \\
$\mathrm{SM}$ & 15.669 & $<0.05$ \\
$\mathrm{CR}{ }^{*} \mathrm{SM}$ & 63.441 & $<0.05$ \\
\hline
\end{tabular}

Information: 
CR: Cognitive Restructuring; SM: Self- TechniquesThe graph of the academic Management; CR\&SM: Combination of procrastination level is presented in Figure 1 Cognitive Restructuring and Self-Management below.

The Level of Academic Procrastination

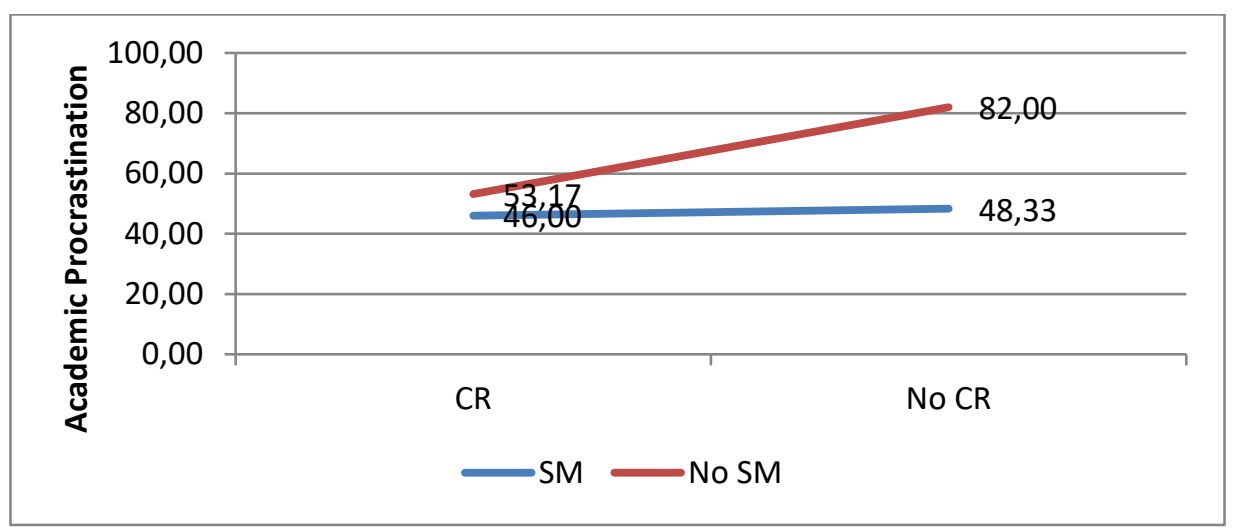

Figure 1. The Level of Academic Procrastination

Figure 1 proved that the group counseling with cognitive restructuring and selfmanagement techniques was effective to reduce students' academic procrastination.

As stated earlier, the current study investigated the implementation of group counseling with cognitive restructuring and selfmanagement to reduce students' academic procrastination. In this way, the researchers performed the effectiveness test to determine the extent to which this intervention affected the procrastination.

The group counseling with cognitive restructuring technique attempted to change negative thoughts into positive ones, acted as a therapy to foster hope and beliefs through through individual thinking styles, and eliminate unnatural behavior including academic procrastination. The way this study researched cognitive restructuring technique to reduce academic procrastination is in line with studies of Dezhkam (2012); Jianxin (2016); Mazaherid (2012); David (2010) which conclude that cognitive restructuring technique can reduce students' academic procrastination.

The group counselling with selfmanagement technique was focused on helping students using their abilities to change specific behaviors independently and responsibly, distinguish the right and proper actions, record appropriate responds, and manage selfreinforcement. Studying self-management technique as an effort to reduce academic procrastination is in accordance with studies conducted by Marcus (2016); Grunschel (2016); Qomariyah (2011); Williams (2010) which found that self-management technique can reduce students' academic procrastination.

Even though studies that employed the above technique have been done by many researchers such as Dezhkam (2012); Jianxin (2016); Mazaherid (2012); David (2010), this study differs in the way it involved Junior High School students as the subjects and focused on academic procrastination, while the previous studies included parents of children with special needs as done by (Dezhkam, 2012), patients (Jianxin, 2010), divorced children (Mazaherid, 2012) people who have problems (David, 2010). For more, this study not only focused on academic procrastination, but also depression.

Based on the results of study, experts' theories, and the findings of previous studies, it could be concluded that the group counselling with cognitive restructuring and selfmanagement techniques is effective to reduce students' academic procrastination so that counselors can make use of it to lower students' academic procrastination. Beck (2011) define cognitive restructuring technique as a counseling 
approach designed to solve counselee's problems by restructuring cognition and deviant behavior. He also adds that the main goal of cognitive restructuring technique is to change students' perspectives through their automatic thoughts and providing ideas to restructure negative thoughts with a rigid belief system.

Furthermore, in applying selfmanagement to reduce students' academic procrastination, a counsellor will lead students to learn using their ability to manage specific behavior to change independently and responsibly. Additionally, students are assigned to distinguish the right and proper behavior, record the right responses and carry out selfreinforcement. However, in its implementation within this study, self-management technique was less effective than $C R$ technique and the combination of CR and SM techniques. It was due to the not optimal efforts by the researchers in implementing this technique, so the students felt less optimal in receiving the treatment.

Apart from its beneficial findings, there was an absence of follow-up to see the effects of time in all four groups.

\section{CONCLUSION}

The current study attempted to examine the effectiveness of the group counseling with cognitive restructuring and self-management techniques to reduce students' academic procrastination. Based on the findings, it is concluded that there are some differences in the effectiveness level of the four groups in the way they reduced students' academic procrastination. Thoroughly, the group counseling with the combination of cognitive restructuring and selfmanagement techniques is more effective to reduce the procrastination than the group counseling which separately utilizes cognitive restructuring and self-management techniques.

Considering the findings, the researchers suggest counselors to use the group counseling with cognitive restructuring and social selfmanagement techniques as an intervention to reduce students' academic procrastination. Meanwhile, the future researchers are recommended to focus on selecting object with different gender, level of education, and providing follow-up activities.

\section{REFRENCES}

Beck, S (2011). Cognitive Behavior Therapy Basic and Beyond (2 d). New York The Guilford Press.

Clare, S., Jenson, W., Kehle, T., \& Bray, M. 2000. Self Modeling as a Treatment For Increasing On-Task Behavior. Psychology in the Schools, 37(6): 517- 522.

Corey, G. 2012. Theory and Practice of Group Counseling, eight editions. California: Brooks/cole.

Corey, G. 2013. Theory and Practice of Counseling and Psichotherapy. Cengange Learning.

David, K.S., Lewandowsky, S., (2011). Restructuring Partitioned Knowledge: The Role of Recoordination in Category Learning. Cognitive Psychology 62: 81122.

Dezhkam, M., Afrooz, G., Matir, A., Looyeh, M.Y. (2012). The Effect of Group Rational Emotive Behavior Restructuring on Mental Health of Parents of Exceptional Children. Social and Behavioral Sciences 46: 1872-1875. DOI: $10.1016 /$ j.sbspro.2012.05.394

DuPaul, G. J., R. E. V., \& Flammer, L. M. 2006. "Attention-Deficit/Hyperactivity Disorder" in Mennuti, R. (Ed.), Freeman, A. (Ed.), \& Christner, R. (Ed.), Cognitive-Behavioral Interventions in Educational Settings. London: Routledge

Erfantinni, I. H., Purwanto, E., \& Japar, M. (2016). Konseling Kelompok CognitiveBehavior Therapy dengan Teknik Cognitive Restructuring untuk Mereduksi Prokrastinasi Akademik. Jurnal Bimbingan Konseling, 5(2), 119-125.

Erford, B. T. 2016. 40 Teknik yang Harus Diketahui Setiap Konselor. Yogyakarta: Pustaka Pelajar.

Flore et al. 2016. Bedtime Procrastination: A Behavioral Perspective on Sleep 
Insufficiency. Computers in Human Behavior 64: 6576.

Grunschel, S., Schwinger, M., Syeinmayr, R. (2016. Effect of Using Motivational Regulation Strategies on Students' Academic Procrastination, Academic Performance, and Well-Being. Learning and Individual Differences 162-170. DOI: 10.1016/j.lindif.2016.06.008

Jianxin Z., Jiang, N., Yu Fei., Zhang, W, (2016). Deficits of Cognitive Restructuring in Major Depressive Disorder: Measured by Textual MicroCounseling Dialogues. Psychiatry Research 238: 159-164 https://doi.org/10.1016/j.psychres.2016. 02.027

Khan, M. J., Arif, H., Noor, S. S., \& Muneer, S. (2014). Academic procrastination among male and female university and college students. FWU Journal of Social Sciences, 8(2), 65.

Maag, J. W. 2004. Behavior Management: From Theoritical Implication to Practical Application $2^{\text {nd }}$. California: Thomson. Wasswoth.

Marcus, E., Ebert, D.D., Lehr, D., Sieland, B., Berking, M. (2016). Overcome Procratination: Enhancing Emoticon Regulation Skills Reduce Procrastination. Learning and Individual Differences 52: $10-18$. https://doi.org/10.1016/j.lindif.2016.10. 001

Mazaherid, E., Zandipour, T., Saadat, M., Ghasemzadeh, A., Karami, S. (2012). Effect of Group Counseling with Cognitive-Behavioral Approach on Reducing Diforce Children's Depression. Procedia - Social and Behavioral Sciences $\quad 46 \quad$ (2012) 77-81. DOI: $10.1016 /$ j.sbspro.2012.05.072

Nursalim, M. 2013. Strategi dan Intervensi Konseling. Jakarta: Indeks.

Ozer, B., Demir, A., dan Ferrari, J.R. 2009. Exploring Academic Procrastination Among Turkish Students: Possible Gender Differences in Prevalence and
Reasons. The Journal of Social Psychology, 149(2): 241-257.

Peters, Erin. 2004. Maximize Student Time On Task. Science Scope, 28(1): 38.

Saputra, R., Purwanto, E., \& Awalya, A. (2017). Konseling Kelompok Teknik Self Instruction dan Cognitive Restructuring untuk Mengurangi Prokrastinasi Akademik. Jurnal Bimbingan Konseling, 6(1), 84-89.

Qomariyah, N. 2011. "Efektivitas Pelatihan Self-Management untuk meningkatkan motivasi berprestasi Siswa SMP". Tesis: Universitas Negeri Malang

Steel, P. 2007. The nature of procrastination: A metaanalytic and theoretical review of quintessential self-regulatory failure. Psychological Bulletin, 133(1), 65-94.

Steel, P. 2010. Arousal, avoidant, and decisional procrastinators: Do they exist? Personality and Individual Differences. Personality and Individual Differences, 48 (8): 926-934.

Tuckman, dkk. 2002. Academic Procrastination: Their Rationalizations and Web-Course Performance. Paper presentation at the American Psychological.

Vargas, J. S. 2009. Behaviour Analysis for Effective Teaching. London: Routledge.

Williams, R.L., Verble, J.S., Price, D.E., \& Layne, B.H. (2010). "Relationship of SelfManagement to Personality Types and Indices". Journal of Personality Assesment, 64(3): 494-506. DOI: $10.1207 /$ s15327752jpa6403_8 